\title{
International Unit per Milliliter per Milligram per Meter Squared
}

National Cancer Institute

\section{Source}

National Cancer Institute. International Unit per Milliliter per Milligram per Meter Squared. NCI Thesaurus. Code C119370.

A unit of concentration (biologic activity) equal to one international unit per milliliter, divided by milligrams per meter squared. 